\title{
4 EMPLOYEES' PERCEPTIONS OF THE EFFECTS OF GREEN TRAINING AND PRACTICES ON HOTEL SUSTAINABILITY IN ILORIN, NIGERIA
}

\author{
Babagbale Elizabeth
}

\begin{abstract}
The current ozone layer degradation and constant environmental pollution occasioned by the activities of tourists and hotel operators among others have continuously endangered human survival in recent times. Despite various attempts by the governments and other stakeholders to mitigate the situation through policies and green practices orientation, the results have not been significantly felt in Nigeria. This paper explores the effects of employees' perceptions of green training and practices on hotel sustainability. Data were collected from a selected sample of 100 employees of four leading hotels in Ilorin metropolis, Kwara State of Nigeria. Hypotheses were tested using Regression analysis. Data were presented through, frequencies, means and standard deviation. The results show significant relationships between green practice and sustainability on one hand, and between green training and sustainability on the other hand. The study also found that hotel employees are willing to implement the training acquired. The study among others recommends green staff training as it could bring about employees' commitment and promote customer retention and increased productivity.
\end{abstract}

Key words: perception, green training, green practices, hotel sustainability, Kwara State

\section{INTRODUCTION}

It is widely acknowledged that going by present trends, the world will become more crowded and polluted, ecologically unstable and susceptible to natural hazards which in the long run could lead to poor quality of life (Fuggle \& Rabbie, 2000). The world is increasingly confronted with environmental issues which are blamed on the activities of various economic sectors, one of which is the hotel industry

The hospitality and tourism industry is one of the world's largest employers (Bulter, 2008). Hospitality industry consists of a wide range of services that include hotels, lodging, restaurants, event planning, theme parks, transportation and cruise liners. The industry contributes about $5 \%$ of the global Gross Domestic Product and employs approximately $8.7 \%$ of the total global workforce which includes approximately
234 million people (Sloan et al., 2013 p.11). All companies within the hospitality industry must integrate sustainable development into their organizations (Bâc, 2012; Conaghan et al., 2015; Mihalic et al., 2012).) Just like any other industry, the hotel industry is concerned with issues related to environmental pollution. Hotel is described as one of the largest consumers of energy, water and other resources which result in a larger amount of wastes thereby increasing the rate of environmental pollution (Mensah, 2019). An average hotel releases between 160 and 200 kilograms of carbon dioxide $\left(\mathrm{CO}_{2}\right)$ per square meter of room floor area per year and water consumption per guest per night is between 170 and 330 litres in the average five-star hotel. On the average, hotels produce $1 \mathrm{~kg}$ of waste per guest per night. (Sloan et al, 2013). A study conducted by Ashrafi, Seow, Lai and Lee (2013) indicated that

Kwara State University, Department of Tourism, Hospitality \& Events Management, Malete Nigeria, Email: lizzybabagbale@gmail.com 
consumption of energy, water and materials while operating a hotel business, accounts for about $75 \%$ of environmental pollution. This clearly shows that the hotel industry is one of the biggest consumers of energy, water and other resources which subsequently results in the generation of a larger amount of waste, thereby increasing the rate of environmental pollution. This actuated the evolution and adoption of green practices in the various operations of hotels globally.

In this modern age, consumers are getting more sensitive to environmental issues, hence they seek products and services that meet their needs and at the same time are environmentally-friendly (Han, Hsu and Sheu, 2010). One of the issues that gave rise to the concept of green staff training is a holistic management process which is responsible for identifying, anticipating and satisfying the requirements of the customers and society profitably and sustainably (Peattie, 1999). Companies can achieve their objectives if they engage in efficient green practices by using limited resources to meet consumers' needs without endangering the livelihoods of future generation (Gitobu \& Njoroge, 2015).

The call for mitigation measures such as the reduction of negative environmental impact is imminent as the world is confronted with several environmental issues (NEPAD, 2019). With increase in travels, the level of waste produced by guests is growing rapidly and the only way to remedy this situation is by reorganizing the existing practices in favour of more environmentally friendly solutions (Baynova, 2018). Punitha, Aziz and Rahman (2016) stated that the hotel industry is a silent destroyer of the environment. Most activities in hotels generate large volumes of waste which harm the environment in later years (Leonidou, Leonidou, Fotiadis \& Zeriti, 2013). Previously, green initiatives were not practised by hotels but recently, environmental issues are drawing global attention due to declining of environmental quality (Teng, $\mathrm{Wu}$ and Liu, 2015). However, guests are increasingly becoming environmentally conscious and are demanding operators to be environmentally compliant as a result, hotels begin to practice recycling, reusing and reducing (Bulter, 2008). A situation like this should draw the attention of researchers and academics alike. Unfortunately, this does not appear to be the situation because hospitality literature has rarely explored the grey area of green marketing practices which makes it an area that needs more research (Rahman, Park and Chi, 2015). The concept of green staff training in the hotel industry is still at its development stage, necessitating an expansion of literature and theory (Myung, McClaren and Li, 2012). With the current focus on sustainable development and environmentally-friendly practices, there is a pressure to follow greening processes in different firms (Sarkis et al., 2010). Poor employees' attitudes towards green practices discourages guests making repeat visits and a dissatisfied guest will tell 8 to 10 potential customers (Xiang et al., 2015). In promoting green performance programmes, the biggest challenge is getting employees to change their behaviour and invest ideas to help implement green practices such as reducing water and electricity waste, proper disposal of refuse among others (Chan, Hon, Chan and Okunmus, 2014). Limited studies have focused on the effects of employees' attitude on green practices of hotels (Mensah, 2009; Mensah, 2019; Ramus, 2002; Sloan et al., 2016; Strandberg, 2009). Unfortunately, these limited studies on the effects of green training and practices on hotels were conducted outside the current study area, that is, Kwara State, Nigeria. Green training and practices is an essential area of study in developing countries particularly in Nigeria where it has been observed that such training and practices are scarce 
(Ajayeoba, 2010; Akintunde, 2017). In Nigeria, environmental management and sustainable development issues have generated serious concern largely because of policy gaps, lack of political will to enforce environmental policies and poor development agenda (Ejumudo and Nwador, 2014). Also in Nigeria, there is no effective policy guiding hotel operation especially in the area of environmental concern (Akintunde, 2017). Green training practice is nonexistent from the programme of some organisations and where it is practised, some do not have a proper record of collection. Many hotel operators have a perception that green practices would require additional cost and feel this will erode their profit margin hence they see it as a major obstacle (Vernon, Essex, Pinder and Curry, 2003).

Akintunde (2017) pointed out that except for Lagos state which has recorded appreciable success in managing over10,000 tons of urban waste daily, other states in Nigeria are still struggling with challenges of inability to cope with the upsurge in the volume of waste due to lack of thorough implementation strategy. Atoki (2017) cited in Akintunde (2017) corroborated Akntunde (2017) that other challenges undermining the country's waste management value include: 'lack of modern technology, policy formulation, strategy implementation, skilled professionals as well as monitoring and control'.

Significantly, recent researches have covered the following: The roles of HRM employees green recovery (Luu, 2018); Predicting patronage intention of a green hotel (Teng, Wu and Liu, 2015); Factors influencing implementation of green practices (Deraman, Ismail, Arafin \& Mostafa, 2017); Hotel sustainable practice from Mediterranean Island (Alipour, Safaeimanesh \& Soosan, 2019). However, with regards to Nigeria, just a few studies have been done on this topic: (Ekong, 2017); (Oyebanji, Adeniji,
Khobai \& Roux, 2017). Even in these few cases, the studies were not specifically on hotels but green growth and green cities in general. None of the studies has covered employees' perceptions of green training and practices on hotel sustainability.

The aim is this study is to explore employees' perceptions of green training and practices on hotel sustainability in Kwara State, Nigeria. This work contributes to the knowledge on green practices, hotel sustainability literature, hotel operations and government policies. First, this research covers the practices of green training among hotel employees and the perceived effects on hotel sustainability. Second, it bridges the knowledge gap on green practices in the hotel industry, especially in the study area. Third, since green practices are designed to influence hotel sustainability, this research will explain the effects of employees green training practices on hotel sustainability by linking it with the strategic choice theory which is based on organisational efficiency using proactive strategies to address critical issues such as sustainability environmental preservation (Child, 1972, 1997). Strategic Choice Theory (SCT) by Child (1972) was chosen to serve as the theoretical foundation for this study. The theory is preferred to the others such as Contingency Theory due to suitability to cross-sectional analysis without limiting the analysis to specific context such as fear of information sources (Shavitt, 1989). SCT allows for less restrictive and multidimensional understanding of green training practices for hotel sustainability.

\section{LITERATURE REVIEW}

SCT is based on the assumption that an organisation is able to achieve high organizational efficiency and performance by proper implementation of strategies within appropriate contexts (Wagner and Bode, 2008). SCT provides the rationale for adopting 
proactive strategies to address critical issues such as sustainability environmental preservation which is green practices. The theory assumes that managers adopt the perspective of strategic choices particularly in dealing with issues that are external to the organization (Child, 1972, 1997). Based on the SCT both the environment and the structure possess the meanings and actions of individuals. Under the theory, managers are perceived to be performing a proactive role wherein they make their choices independently, while their actions serve as energising forces that shape the organisational world (Astley and Van de Ven, 1983). Hence, within the context of sustainable development, SCT implies that the proactive response of top leadership results in a high level of commitment to green initiatives and relational orientation over time. Therefore, the important factor that must be considered based on SCT is translating managerial perception into strategic commitments that the organisation and its employees must sustain to address obvious and emerging stakeholders' pressures (Jørgensen and Jørgensen, 2009). In summary, proactive responses to green issues allow companies to meet emerging market opportunities and ensure competitive advantage (Andersson and Bateman, 2000; Sharma, 2000; Sloan, 2013).

Under the SCT, Child (1972) argued that companies are free to choose strategically from available options when developing a process or structure. On the other hand, strategic decision-makers experience a degree of constraint, based on contextual factors (Wagner and Bode 2008). From a strategic choice perspective, aligning the resources of an organisation with its organizational context may be perceived as a primary and important task for the strategic decision-makers. These decision-makers must always consider any potential environmental threats and opportunities as they evaluate the alternatives they have, in order to arrive at the most appropriate and strategically fit choice for the constantly changing environment (Miles and Snow 1978, Venkatraman and Camillus 1984). Therefore, organizations should be repositioned relative to the issues they would want to address based on the SCT (Ketchen and Hult 2007). Accomplishing this will enable companies to improve in terms of adaptability to the demands of the organizational environment, as seen in the orientation of the strategies they implement which is called strategic orientation (Ponomarov, 2012).

Experts believe that training is an important aspect of human resource management which facilitates a company's advancement in its competitive stance relative to other similar players in an industry (Sarkis et al. 2010). Green hotels are enterprises which favour sustainable living techniques without compromising the comfort of the guests. According to (Banova, 2018) some of the strategies to achieve this are: energy conservation since excessive energy use is of no benefit (Cingoski \& Petrevska, 2018, Caulifield, 2019). Also, water wastage through leakages, pipe burst, gardening could be reduced by implementing a zero-waste policy and establishing a recycling process (Culligan, 2018).

Aquinis and Kraiger (2009) listed the different benefits of training to be characterized as one of three forms: (a) individual level, (b) organizational level, and (c) societal level. At the individual level, the different favourable effects of training include innovation and tacit skills, improvement of adaptability, improved skill in the technical and self-management aspects of organisational performance and improved ability to adjust to cultural diversity. Other indirect benefits include: team's task coordination, improved planning skills, better communication and employee empowerment (Aquinis and Kraiger, 2009). At the organisational level, training leads to improved overall 
performance as reflected in the organisation's operating revenue per employee, productivity, effectiveness and overall profitability. Other improvements at the organisational level include reduced costs and enhanced product or service quantity and quality (Aquinis and Kraiger, 2009). At the societal level, many countries adopt policies at a national level to influence the development and implementation of training programs for the overall improvement of its human resource pool, which in turn add value to the economy (Aquinis and Kraiger, 2009).

Green or environmental training is defined as an organized and systematic effort to develop a program for the modification and development of green-related knowledge, skills and behaviour by means of imparting knowledge through experiences of environmental issues (Aquinis and Kraiger, 2009; Daily and Bishop, 2012; Sarkis et al. 2010). Green Training USA (2020) stated that green training can mean energy efficiency, indoor air quality and sustainability. Green Human Resources Management (GHRM) is the use of Human Resources Management (HRM) strategy to encourage sustainable use of resources within the organization. GHRM is seen to be a potential study area in developing countries as it improves environmentalism. Folk (2015) defined green training as the pursuit of knowledge and practice that lead to environmentally friendly and ecologically responsible decisions and lifestyle which can help protect the environment and sustain the natural resources for present and future generations. Green hotels refer to hotels that attempt to be more environmentally friendly in terms of efficiency and optimum usage of energy, water and materials while at the same time providing quality service. Green training comprises programmes that encourage hoteliers to save water, energy, reduce solid waste, reduce operational cost and at the same time protecting the earth.
According to Manaktola and Jauhari (2007), certain names like an eco-friendly hotel, environmentally-friendly hotel and green hotel are terms used for hotels that are geared towards green practices of which some are: conservation of water and energy and the reduction of solid waste. The benchmark for successful green hotels is the application of the $3 R s$ namely Reduce, Reuse and Recycle. These have been adopted by certain hotels around the world in their quest to become environmentally-friendly and have become more responsible in the reservation of resources by utilizing water and energy with caution as an acceptable way of operating the business (Tzschentke, Kirk and Lynch, 2004). Part of the goals of 3Rs is to minimise waste, preserve natural resources and conserve energy. In environmental education, 3Rs synthesises a guideline to assist in the fight for environmental conservation. This is explained as reduce consumption to the minimum necessary, reuse what can still be used and recycle by turning waste into a resource for new life. However, in recent times a new concept has emerged adding another 3 Rs namely, revaluation of resources, redistribution of income and relations thereby moving from 3Rs to 6Rs. Yet more recently, there has been the addition of another 3Rs as: resilience (adaptability), reassessment (scale value) and restructuring (of the economy) thereby giving a total of 9Rs (Acciona, 2019). Green hotels are proactive about reducing resource waste and recycling. They also engage in giving guests reusable stainless-steel water bottles to discourage the use of disposable bottles (Folk, 2015)

A study by the Cornell University, Center for Hospitality Research in 2015 revealed that hotels are facing 'a green-tinted dilemma'. Guests now want the hotels to operate sustainability programmes on their own terms which involve care for the environment and at an affordable price. Though they want green hotels with 
maximum comfort, they are not willing to pay more. The hotel operators have to work out sustainable operations by putting essential facilities in place to keep the guest smiling and yet run the organisation at a profit in order to remain in business. Highly educated and well-informed guests are enlightened about effective hotel sustainable programmes than mere energy efficiency. Guest would not be cajoled into accepting 'eco-certified' label just for the sake of it. More often than not they would ask specific questions about the green practices of the hotels. Consequently, hotels that do not implement green initiatives to the letter are doing so at their peril. Another study at Cornell revealed that green hotels reward guest's participation and have discovered that guests are more willing to participate in sustainability when they get something in return such as Loyalty points and not necessarily monetary reward per se (Dominguez, 2015).

A typical green hotel saves electricity consumption by about $10 \%$, which is significant as costsaving for the hotel. However, the programmes of sustainable hotels should be visible and with remarkable improvements such as planting on rooftops, use of solar panels, low-flow showerheads, Compact Fluorescent Lamp (CFL) lighting, energy-efficient appliances and flow toilets (Dominguez, 2015). Sun-Hwa (2009) conducted an empirical investigation of hotel employees' perception of green practices working in Orlando. The study adopted a descriptive cross-sectional survey of 220 employees in the eight certified hotels. The results revealed that performance levels of green practices implemented by hotels were lower than the importance levels of those same green practices as perceived by hotel employees. More so, it was found that employees' perception of green practices was not different than one of the hoteliers in terms of performance, and employees weighted the green practices that were beneficial to them as more important than those required to change their behaviour. The study thus recommends green practices for organizational overall benefits than for individual benefits.

Sun-Hwa Kim and Youngsoo (2013) conducted another related empirical study on hotel employees' perception of green practices focusing on deployment of green practices in hotels. The perspective of hotel employees was examined with a survey of 220 employees working in 8 green certified hotels in Florida, United States. Drawing on the data collected and analysed, the result revealed that the correlation between green practices and organizational commitment was statistically significant. Among the variables used, water conservation had a strong correlation to organizational commitment, followed by recycling. More so, performance of clean air was strongly correlated to organizational commitment; while, recycling showed the weakest but still significant correlation with organizational commitment. The study thereby recommends green training and deployment of green practices among hotel employees.

Investigating sustainable practices in the hotel industry from employees' perspective, Alipour, Safaeimanesh and Arezoo (2019) conducted a research on the Mediterranean Island with a survey of 300 hotel employees. From the data collected and analysed, the study revealed that employees are a legitimate and credible source of information about sustainability practices. It is also revealed that as going green gradually becomes a means of branding, hotels under study are making efforts to implement genuine sustainability practices. Study also revealed that the majority of employees validated the sustainability practices as genuine and appropriate for hotel business growth. The study hence recommended that sustainable 
practices should be inculcated into employees' training and orientation programmes.

In an attempt to investigate if there is a benefit from being green, Rachel Dodds and Mark Holmes (2016) conducted a research among North American Hotels. A total of 2,248 structured surveys were carried out among hotels that participated in the Green Key Certification Scheme across North America. The results of the findings show that the extent to which hotels perceive they benefitted from marketing sustainability practices through guest visits, guest length of stay, guest satisfaction, revenue, profit, and average daily rate can be predicted in relation to the extent to which a hotel believes that green marketing has been incorporated into hotels' green marketing strategy. The study, therefore, recommended the incorporation of green marketing into hotels' green marketing strategy.

On examining hotels' consumer attitude about ecology and perception of the green hotel, Zainuddin, Riazi, Rashid, and Nawi (2018) conducted research among hotel guests in Malaysia. The research adopted a quantitative approach and data was collected from 51 hotel customers. A total of 115 copies of questionnaire were distributed. The findings from the research showed that consumers have in recent times had a positive environmental attitude. The study found that consumers agree with the importance of environmental awareness and the need for awareness to be raised among Malaysians. The study further found that green products purchasing are mutually correlated with green practices among the respondents. Green products are seen to be able to reduce the carbon emission which is one of the ways to handle environmental issues hence recommended.

Chang-Hua, Chien-Yu and Teng (2013) examined the relationship between perceptions of environmental management and employee job attitudes.
A survey method was employed to collect data from employees of 20 international tourist hotels in Taiwan.

A total of 506 online questionnaires were mailed while a total of 312 copied representing $61.7 \%$ response rate were duly completed and returned. The findings of the study reveal that energy management, green procurement, organizational system/ control, and external relationships positively correlated with employees' job satisfaction, while on the other hand, energy management, organizational system/control, and external relationships positively correlated with organizational commitment. The study thereby recommended continuous adoption of green environmental practices as it influences employees' job attitude and commitment.

A phenomenology inquiry into hoteliers' perceptions of sustainable practices on small hotel optimization was made by Keneika Rowe (2018) in Jamaica. The purpose of the study was to explore liveexperiences of employees of eight hotels on the effect of sustainable practices on hotel sustainability. Being a qualitative research, data were collected through unstructured interviews and observations from the five most visited hotels in Jamacia. Results revealed that sustainable practices such that should include education on the history, culture, and heritage and respecting the environment are inherent to sustainability of small hotels in Jamaica. The findings showed that high cost was a major factor for poor sustainable practices in small hotels. More so, findings revealed that there was a need for government assistance in providing funding and education on the benefits of sustainable practices and development in the tourism and hospitality industry in Jamaica.

From the above, it is hypothesized that:

$\mathrm{H}_{1}$ : Green practices has no significant effect on the perception of hotel sustainability. 
$\mathrm{H}_{2}$ : Green training has no significant effect on hotel perception of hotel sustainability

\section{METHODOLOGY}

This study used a descriptive research design. It employed a quantitative research approach through the collection of data by questionnaire from the employees to facilitate diversity of the results (Johnson \& Onwueghuzie, 2004; Creswell \& Plano Clark, 2007). The study area is Ilorin the capital of Kwara State, Nigeria. Kwara which has a population of over 2 million, is a landmark in the middle belt of Nigeria and sandwiched between Lagos, Nigeria's chief commercial city and Abuja the Federal capital. It is a convenient stopover for trips by road between Lagos, Abuja and vice- versa. It is known as a state of harmony as a result of the peaceful co-existence of both the indigenes and visitors. This is why guests prefer the state particularly Ilorin to some other states in the country hence it is a popular destination for conferences while the hotels are well patronised. In Ilorin metropolis, aside from 114 budget hotels, there are 171 registered hotels of different categories such as: budget hotels and 1-5 star hotels. The list of the hotels was obtained from Kwara State Tourism Board and the Ministry of Culture and Tourism. Four hotels which were in the 3 and 4- star categories were then selected for this work adopting the Krejcie and Morgan (1970) table for determining sample size. In all, 100 questionnaires were distributed. The researcher considered the size manageable.

Both probability and non-probability sampling methods were used. Stratified random sampling was used to select the hotels from each category and stratified random sampling procedure adopted to select the employees whereby the list of employees based on hotels was disaggregated or segmented into two strata, namely 3-star and 4-star hotels. Based on that, a proportional allocation of the number of hotels were selected from the different categories of hotels. The purposive sampling was used to select the four hotels. Two of the hotels from each group which were known to actively engage in green practices were selected. Following this, the multi-stage technique was employed to select 100 employees from the hotels involved in the study. Firstly, a list of all the employees in the hotels that were involved in the study was obtained. The next phase involved the proportional allocation of the sample size among each hotel such that hotels with large population size obtained large sample size (i.e. the total population of employees in each hotel was divided by the total population of employees for all the four hotels and the result was multiplied by the total sample size for the study i.e. 100). This procedure was applied to all the four hotels until the total sample for each hotel was obtained. The simple random sampling procedure, specifically the lottery method was used to select the employees from each hotel to be involved in the study.

The instrument used to collect data was a selfadministered questionnaire (Bhandarkar \& Wilkinson, 2010; Deng, 2010; Amedahe \& Gyimah, 2005). The instrument was divided into three sections. Section A covered the background and characteristics of the respondents such as gender, age, educational background and work experience. Section B comprised of items considered as green training and practices. Section $\mathrm{C}$ of the questionnaire solicited information about employees' perceptions of sustainability in the hotel industry. The questions were arranged in a systematic order with both open and closed-ended questions to ensure easy and rapid response. A fourpoint Likert scale ranging from 1 (strongly disagree) to 4 (strongly agree) was used to determine the influence of green training practices on hotel sustainability. 
Personal calls were made to the hotels by the researcher and the field assistant to ensure a high response rate.

Face and content validity checks were conducted by academic expert and a seasoned hotel human resource manager were consulted to assess whether the statements were relevant and properly structured (Chen and Huang, 2017). The questionnaire was designed in English because English is the official language in Nigeria and the hotel employees are educated. Questionnaires were self-administered to 100 hotel employees of the four hotels in Ilorin metropolis.

Before data collection, the researcher presented copies of an introductory letter to the managers through the human resource managers for the managers' and consent. The respondents were briefed concerning how to respond to the items and supervised by the researcher to complete the questionnaire. The data collection time was agreed with the respondents so as not to interfere in their daily routines.

Out of 100 questionnaires that were administered, 96 were deemed useful for analysis. Out of the 4 that were excluded from the analysis, it was realized that some questions that are key to the study were not answered. For instance, some did not respond to the issues of age, educational background and hotel sustainability. Descriptive methods like frequencies, means, standard deviations and simple percentages and regression were used for analysing the data.

Hypotheses were tested using a regression analysis. Data were analysed and presented systematically beginning with the demographic information of the respondents, followed with the research questions and hypothesis that guided the study. The data gathered from employees and were analysed through the computation of frequencies, percentages, mean of means distributions, independent samples t-test and ANOVA.

\section{RESULTS}

\section{Green Practices of Hotels}

Table 1 reveals that the respondents agreed to all the statements relating to green practices as indicated by the mean. All the 11 constructs have mean ranging from 3.03 to 3.64 and standard deviation ranging from 0.59 to 0.76 . The table has a calculated average mean of 3.42 and a standard deviation of 0.68 , which shows the respondents strongly agreed to three constructs namely towel/linen reuse, recycling and energy conservation and agreed to the other eight constructs.

\section{Table 1: Green Practices of hotels in Kwara State}

\begin{tabular}{lcc}
\hline Green practices & $\overline{\mathrm{X}}$ & $\mathrm{SD}$ \\
\hline Towel/Linen Reuse Program & 3.64 & 0.63 \\
Offering recycling for some of the most common materials, including paper, aluminium and plastic & 3.57 & 0.62 \\
containers & 3.55 & 0.59 \\
Conserve energy & 3.43 \\
Limited resources will be required to meet customer's need if green practices are adopted by the & 0.74 \\
hotel management. & 3.42 \\
Allowing guests to control the temperature in their rooms & 3.42 \\
Equip staff with eco-friendly cleaning suppliers & 3.39 & 0.75 \\
Offer conventional products alongside organic fruits, salads and packaged products & 3.39 \\
Limit water waste & 3.39 \\
The hotels that gear towards green practices are referred to as environmentally friendly. & 0.64 \\
The hotels that gear towards green practices are referred to as environmentally friendly & 3.34 \\
Clean towels upon request only & 3.03 \\
Weighted average & 3.42 & 0.76 \\
& 0.68
\end{tabular}

Source: Field Survey, 2019 
This implied that towel/linen reuse program, offering recycling for some of the most common materials, including paper, aluminium and plastic containers and conserve energy are the common green practices in the hotels.

\section{GREEN TRAINING GIVEN TO EMPLOYEES}

Table 2 reveals that the respondents agreed to ten statements relating to green training with mean ranging from 3.27 to 3.44 and indicated they strongly agreed to training on hotel policy on water conservation

Table 2: Green training given to employees

\begin{tabular}{lcc}
\hline Green training & $\overline{\mathrm{X}}$ & $\mathrm{SD}$ \\
\hline$\cdot \quad$ Policy for water-saving by the tourists & 3.54 & 0.80 \\
Movement detectors for controlling lights in public areas. & 3.53 & 0.70 \\
- Use of recycled paper for administrative purposes & 3.44 & 0.70 \\
Hotel employees are to be trained to prevent water wastage. & 3.42 & 0.77 \\
Policy for energy saving by the employees & 3.39 & 0.81 \\
Cleaning with bio-degradable substances & 3.35 & 0.81 \\
Hotel employees need to be trained on proper waste disposal to prevent environmental pollution & 3.35 & 0.80 \\
Employees green training can influence guest patronage & 3.30 & 0.90 \\
Hotel employees are to be trained on proper disposal to enhance hotel efficiency & 3.29 & 0.83 \\
The employees should be trained on how to conserve energy for efficiency of the hotel & 3.27 & 0.76 \\
Weighted average & 3.39 & 0.79 \\
\hline
\end{tabular}

Source: Field Survey, 2020

and use of movement detectors for controlling lights. All the 10 items have a standard deviation ranging from 0.70 to 0.90 .

This means that the responses of the respondents are not widespread but they are close to the mean. This implies the hotels offer training to their employees mainly in the areas of energy and water conservation.

\section{Perception of Hotel Sustainability}

The result presented in Table 3 shows the responses on employees' perceptions of hotel sustainability. The results revealed that respondents agreed to all the constructs with mean ranging from 2.59 to 3.22. All the constructs have standard deviation ranging from 0.90 to 1.01 which means that the responses of the respondents are not widespread as they are close to the mean.

Table 3: Perception of Hotel Sustainability

\begin{tabular}{lcc}
\hline Item Statements & $\bar{X}$ & SD \\
\hline $\begin{array}{l}\text { Guests repeat patronage can boost productivity } \\
\text { The consumption of energy and other materials in the hotel contribute to environmental }\end{array}$ & 3.22 & 0.96 \\
pollution & 0.90 \\
The consumption of water and other materials in the hotel contribute to environmental & 3.03 & 1.01 \\
pollution & 3.03 & 1.01 \\
The hotels geared towards green practices are referred to as environmentally friendly. & 0.90 \\
Less resources will be required to meet customer's need if green practices are adopted by the & 2.59 \\
hotel management. & 2.98 & 0.96 \\
Weighted Average & &
\end{tabular}

Source: Field Survey, 2019 
Thus, employees of the hotels believed that repeat patronage and green practices are important for the sustainability of hotels. Also, energy and water consumption could hamper the sustainability of hotels.

\section{Hypotheses Testing}

The test of significance results as presented in Table 4 showed that green practices had a statistically significant influence on Perceived hotel sustainability
$\left(\mathrm{B}=0.857 ; \mathrm{t}_{(94)}=26.480, \mathrm{P}=0.000\right)$. It indicated that at $5 \%$ level of significance there is enough evidence that the regression equation is well specified, that a significant relationship exists between green practices and hotel sustainability. Based on this, the null hypothesis was rejected and it was concluded that green practices have a significant influence on perceived hotel sustainability.

Table 4: Regression Analysis of Green practices and Hotel Sustainability

Dependent Variable: Perception of Hotel Sustainability

Independent Variable: Green Practices

Table 5: Regression analysis of green training and hotel sustainability

\begin{tabular}{|c|c|c|c|c|c|c|c|c|}
\hline \multirow{2}{*}{\multicolumn{2}{|c|}{ Model }} & \multicolumn{2}{|c|}{$\begin{array}{l}\text { Unstandardized } \\
\text { Coefficients }\end{array}$} & \multirow{2}{*}{$\begin{array}{l}\text { Standardized } \\
\text { Coefficients } \\
\text { Beta }\end{array}$} & \multirow[b]{2}{*}{$\mathrm{t}$} & \multirow[b]{2}{*}{ Sig. } & \multicolumn{2}{|c|}{ 95\% Confidence Interval } \\
\hline & & $\mathrm{B}$ & Std. Error & & & & Lower Bound & Upper Bound \\
\hline \multirow[t]{2}{*}{1} & (Constant) & .126 & .201 & & 0.626 & .535 & .455 & .785 \\
\hline & Green training & .967 & .059 & .929 & 16.516 & .000 & .802 & .973 \\
\hline
\end{tabular}

$. \mathrm{R}^{2}=0.864 \quad$ Adj $\mathrm{R}^{2}=0.861$

Dependent Variable: Perception of Hotel Sustainability

Independent Variable: Green Training

The test of significance results as presented in Table 5 showed that green training had a statistically significant influence on perceived hotel sustainability (B $\left.=0.967 ; \mathrm{t}_{(94)}=16.516, \mathrm{P}=0.000\right)$. It indicated that at $5 \%$ level of significance there is enough evidence that the regression equation is well specified that a significant relationship exists between green training and hotel sustainability and therefore it influenced employees' perceptions of hotel sustainability. Based on this, the null hypothesis was rejected and it was concluded that green training given to employees has a significant influence on perceived hotel sustainability.

\section{DISCUSSION OF FINDINGS}

The study found that training on green practices has significant influence on employees' perceptions of hotel sustainability. This finding is consistent with the literature which indicate that green 
training that have been designed for pro-environmental values and behaviours among employees can be utilized to implement sustainable strategies (Tang et al, 2018; Renwick, Jabbour, Muller-Camen, Redman \& Wilkinson, 2016). Green staff training practices in the hotel industry could be seen as an opportunity and a good marketing strategy that could yield a competitive advantage for hotels (Manaktola \& Jauhari, 2007) especially when it positively impacts on customer interests and hotel sustainability. This means that when proper green training is practised such as: energy conservation, cleaning with environmentally friendly detergents, use of recycled paper for administrative purposes as well as the adoption of the 6Rs by employees and management. Hotel employees are to be trained on proper waste disposal which can enhance hotel efficiency and sustainability.

\section{CONCLUSIONS AND RECOMMENDATIONS}

Based on the findings, the following conclusions and implications are proffered.

Undoubtedly, hotels in Kwara state are facing almost the same challenge and it might be a good idea for them to jointly organise green training for their employees and thereby save costs._Kwara state should implement green strategies, practices and processes that will enhance business operations. The country at large needs to develop a holistic waste management plan and encourage Public-Private Partnership (PPP) based on the principle of reduce, re-use, recycling and disposal.

This study has its limitations. Firstly, it did not cover all the categories of hotels. Specifically, only 3-4 star hotels were captured, a future study could investigate the lower star- rated hotels. Secondly, it adopted only a quantitative approach. A future research should attempt a mixed approach which involves both quantitative and qualitative analyses. Thirdly, only employees and their supervisors were engaged in filling perceptions of the hotels' management staff. the questionnaires, a future study could look at the

\section{REFERENCES}

Acciona (2019). Sustainability for All', Retrieved from: https:// www.acciona.com.

Akintunde (2017). Effective Waste Management crucial for sustainable development', Globetech Ramedial Nigeria Limited reported by The Guardian. Retrieved from: hittps://www.guadian.ng>property>effectsofgre enpractices of 02 January 2017 @ 1.40am

Alipour, H., Safaeimanesh, F. and Soosan, A. (2019) Investigating sustainable practices in Hotel Industry from Employees' perceptive: Evidence from a Mediterranean Island. https://www.mdpi.com of November 202019

Amedahe, F. \& Asamoah-Gyimaah, E. (2005). Introduction to Research Methods in Education, Accra: Mercury Press.

Anderson, J. C., \& Bateman, D.W. (2000). Structural equation modeling in practice: a review and recommended two-step approach. Psychological Bulletin, 103(3),411- 423.

Aquinis, T. A., \& Kraiger, R. (2009). The implementation of green hotel management standard in Majapahit hotel Indonesia, International Journal of Organizational Innovation, 9(3).

Ashrafi, A., Seow, H. V., Lai, S. L., \& Lee, C. G. (2013). The efficiency of the hotel industry in Singapore, Tourism Management. 37(3), 31-34.

Astley, J.S., \& Van de Van, T.S. (1983). Estimating nonresponse bias in mail surveys, Journal of Marketing Research. 14(3), 396-402. 
Bâc, D. P. (2012). The impacts of tourism on society. Annals of the University of Oradea, Economic Science Series, 21, 500-506.

Bay-nova, Y, (2018). The green guide to sustainable hotel practices, Retrieved from: https://wwwcm.clock-software.com of .14 .4 .2020

Bhandarkar, PC. \& Wilkinson, TS. (2010). Methodology and Techniques of Social Research, Mumbai: Himalaya.

Butler, J. (2008). The compelling hard case for green hotel development, Retrieved from: https://www.researchgate.net.

Cayuga (2015). Sustainable Stategies of Green hotels, Retrieved from: https:/www.hamiltonbeachcommercial.com, 2015.

Chan, E. S., Hon, A. H., Chan, W., \& Okumus, F. (2014). What drives employees' intentions to implement green practices in hotels? The role of knowledge, awareness, concern and ecological behaviour. International Journal of Hospitality Management, 40, 20-28.

Child, J. (1972). Organizational structure, environment and performance: The role of strategic choice, Sociology. 6(1), 1-22.

Child, J. (1997). Modularised eco-innovation in the auto industry. Journal Clean Production, 19, 212-220.

Conaghan, A., Hanrahan, J., \& McLoughlin, E. (2015).

The attitudes of the key stakeholders on sustainable tourism in Ireland: The holidaymaker and tourism enterprise perspective. Turizam: međunarodni znanstvenostručni časopis, 63(3), 275-293.

Creswell, J. W., \& Zhang, W. (2009). The application of mixed methods designs to trauma research. Journal of Traumatic Stress: Official
Publication of The International Society for

Traumatic Stress Studies, 22(6), 612-621.

Deng, H. (2010). Emerging patterns and trends in utilizing electronic resources in a higher education environment: an empirical analysis. New library world, 111(3-4), 87-103.

Deraman, F., Ismail, N., Mod Arifin, A. I., \& Mostafa, M. I. A. (2017). Green practices in hotel industry: Factors influencing the implementation. Journal of Tourism, Hospitality \& Culinary Arts (JTHCA), 9(2), 1-12.

Dominguez (2015). What are some of the sustainable strategies of green hotels, Retrieved from: https://www.hamiltonbeachcommercial.com.

Drexhage, J., \& Murphy, D. (2010). Sustainable development: from Brundtland to Rio 2012. United Nations Headquarters, New York, 2010, 9-13.

Ekong, F. U. (2017). Applying The Concept Of Green Cities In Nigeria: Challenges And Prospects. Advances in Social Sciences Research Journal, 4(10).

Folk, E. (2015). Going Green, Retrieved from: http://www.thrall.org of 14.4. 2020.

Fuggle, N., \& Rabie, C.,(2000). Who's reading the label? Millenials' use of environmental product labels. Journal of Applied Business and Economics. 10(3), 1-12.

Galpin, T., Whitttington, J. L., \& Bell, G. (2015). Is your sustainability strategy sustainable? Creating a culture of sustainability. Corporate Governance, 15(1), 1-17.

Gitobu, J. \& Njoroge, J. (2015). Adoption of green marketing practises by hotels in Mombasa County, Kenya, African Journal of Tourism, Hospitality and Leisure Studies. 1(1), 1-18.

Han, H., Hsu, L. T. J., \& Sheu, C. (2010). Application of the theory of planned behavior to green hotel 
choice: Testing the effect of environmental

friendly activities. Tourism management, 31(3), 325-334.

Hashmi, M., Damanhouri, A., \& Rana, D. (2015). Evaluation of sustainability practices in the United States and large corporations, Journal of Business Ethics. 127, 673-681.

Johnson, R. B., \& Onwuegbuzie, A. J. (2004). Mixed methods research: A research paradigm whose time has come', Educational researcher. 33(7), 14-26.

Jorgensen, A. W., \& Jorgensen, R. L. (2009). The contingent effect of specific asset investments on joint action in manufacturer-supplier relationships: An empirical test of the moderating role of reciprocal asset investments, uncertainty, and trust, Journal of the Academy of Marketing Science. 27(3), 291-305.

Krejcie, R.V., \& Morgan, D.W. (1970). Determining sample size for research Activities, Educational \& Psychological Measurement. 30, 607-610.

Kumaransingue, K. \& Pallewaththa, P. (2018). The effect of Green Training and Development Practices on Employees' Performance (Jafina)', The $2^{\text {nd }}$ Research Conference on Business Studies (RCBS- 2018) Smart of 14.4.2020

Legrand (2020). Legrand and the Sustainable Development Goals (SDG), Retrieved from: https://www.legrandgroup.com 8 May 2020

Leonidou, C. N., Leonidou, H., Fotiadis, C. S., \& Zeriti, N. A. (2013). Greening" the marketing mix: do firms do it and does it pay off? Journal of the Academy of Marketing Science, 41(2), 151-170.

Luu, T., \& Vo, T. (2018). Charismatic Leadership and Public Service Recovery Performance, Marketing Intelligence and Planning, 36(1), 108123.
Manaktola, K., \& Jauhari, V. (2007). Exploring consumer attitude and behaviour towards green practices in the lodging industry in India. International Journal of Contemporary Hospitality Management. 19(5), 364-377.

Mensah, I. (2019). Environmental Management Concepts and Practices for the Hospitality Industry, Cambridge Scholars Publishing: UK

Mensah, I. \& Mensah, R. (2013). Management of Tourism and Hospitality Services, $2^{\text {nd }}$ ed. Xlibris Ltd: UK.

Mensah, I. (2014). Different shades of green: Environmental management in hotels in Accra, International Journal of Tourism Research, 16, $450-461$.

Mihalic, D., \& Ozretic-Dosen, D., Hayes, D., \& Ninemeier, J. (2012). Greening hotels- building green values into hotel services. Tourism and Hospitality Management, 20(1), 85-102.

Myung, E., McClaren, A., \& Li, L. (2015). Environmentally related research in scholarly hospitality journals: Current status and future opportunities, International Journal of Hospitality Management. 31(4), 1264-1275.

Oyebanji, I., Adeniji, B., Khobai, H. and Roux, P. (2017). Green Growth and Environmental Sustainability in Nigeria, International Journal of Energy Economics \& Policy, 7(4)

Peattie, K. (1999). Trappings versus substance in the greening of marketing planning, Journal of Strategic Marketing. 7(2), 131-148.

Punitha, S., Aziz, Y. A., \& Rahman, A. A. (2016). Consumers' Perceptions of Green Marketing in the Hotel Industry. Asian Social Science, 12(1), 1. 
Rahman, I., Park, J., \& Chi, C. G. Q. (2015). Consequences of "greenwashing" Consumers' reactions to hotels' green initiatives. International Journal of Contemporary Hospitality Management, 27(6), 1054-1081.

Renwick, D., Jabbour,C., Mullen- Camen, M., RedmAn, T. \& Wilkingson, A. (2016). Contemporary development in Green (Environment) HRM Scholarship, The International Journal of Human Resources Management, 27(2), 114-128.

Rifai, T. (2017). What a sustainable hotel really is, and what it takes to become one, Retrieved from: http:// www.ferrerhotels.com, 2017.

Sarkis, J., Gonzalez-Torre, P., \& Adenso-Diaz, B. (2010). Stakeholder pressure and the adoption of environmental practices: The mediating effect of training, Journal of Operations Management. 28(2), 163-176.

Sloan, P., Legrand, W., \& Chen, J. S. (2013). Sustainability in the hospitality industry: Principles of sustainable operations. London, England: Routledge.

Sloan, P. (2016). Sustainability in the Hospitality Industry: Principles of Sustainable Operations. London, England: Routledge.

Stranberg (2006) 'The Business case for sustainability', Retrieved from: https://www.businessperformance.org
Tang, G, Chen, Y., Jiang, Y., Paille, P. \& Jia, J. (2018). Green Human Resource Management practices: Scale development and validity, Asia Pacific Journal of Human Resources, 56(1), 31-55

Teng, C. C., Horng, J. S., \& Hu, I. C. (2015). Hotel environmental management decisions: The stakeholder perspective. International Journal of Hospitality \& Tourism Administration, 16(1), 78-98.

Tzschentke, N., Kirk, D., \& Lynch, P. A. (2004). Reasons for going green in serviced accommodation establishments, International Journal of Contemporary Hospitality Management, 16(2), 116-124.

Venkatraman, N., Camillus, D. R. (1984). Strategic orientation of business enterprises: the construct, dimensionality and measurement. Management Science, 35(8), 942-962.

Wagner, S. M., \& Bode, C. (2008). An empirical examination of supply chain performance along several dimensions of risk, Journal of business logistics. 29(1), 307.

Warren HyB (2019). Sustainability Hospitality, Retrieved from: www.hotelyearbook March 5 2019. 